\title{
The Quality of School Life of Vocational High School Implementing Long-Distance Learning (A Case Study of " $X$ " Vocational High School in Jakarta During the Covid-19 Pandemic)
}

\begin{abstract}
Synthia Synthia ${ }^{1}$ Monika Monika ${ }^{1 *}$
${ }^{I}$ Faculty of Psychology, Universitas Tarumanagara, West Jakarta, Indonesia

*Corresponding author. Email: monika@fpsi.untar.ac.id

ABSTRACT

$\mathrm{X}$ vocational high school Jakarta, which is located in the central city of the Indonesian economy with a variety of industries, is a vocational school in the field of accounting and office administration. The role of vocational education in preparing students as human resources needed in the job market, requires a good quality of school life. The quality of school life is a student's view of satisfaction and experiences at school. This study examined the quality of school life at X Vocational High School Jakarta which conducted long distance learning during the Covid-19 pandemic.This study is a descriptive quantitative study which uses Quality of School Life measuring instrument by Ainley \& Bourke in Leonard (2002) which have been modified to adapt to remote learning situations during the Covid-19 pandemic. This study involved 118 students of X Vocational High School Jakarta consisting of 50 male participants and 68 female participants. The results found a mean of 2.7796 , indicating that the quality of school life is high. In addition, open-ended questions were asked by the authors to draw a picture of long distance learning from the students' point of view. The analysis of open-ended questions shows that students are comfortable with long distance learning due to the effectiveness and efficiency of the study time. However, the assignments and the process of delivering the material is the drawback of long distance learning, according to students
\end{abstract}

Keywords: Quality of School Life, Vocational High School, Long Distance Learning, and Covid-19 Pandemic

\section{INTRODUCTION}

The sudden implementation of long-distance learning as an effort to prevent the spread of Covid-19 forces students and teachers to adapt to a different learning system than usual. Hong et al conducted a comparative study of traditional learning processes with long distance learning conducted through a survey given to teachers and students in China. The results showed that in general, the teachers and students were satisfied with either of the learning methods, but the research also showed that more time was needed to prepare learning materials. Based on the results of research [1], it was also found that the adaptability, expressiveness, and accuracy of students in answering questions were lower than traditional learning method.

The authors conducted a preliminary survey related to the phenomenon of long distance learning at $\mathrm{X}$ vocational high school in Jakarta to find out an overview of the implementation of long distance learning. Based on a survey of 19 students, the researcher found that $57.9 \%$ of students liked both long distance learning and traditional learning. A total of $52.63 \%$ of students also answered that according to them long distance learning can be conducted effectively. The reason given by the students was that they felt that long distance learning has several advantages, but it needed to be further improved, especially in delivering the materials to make it easier for students. A total of $26.32 \%$ of students considered learning using the long distance learning method to be ineffective on the grounds that the materials given were more difficult to understand and that there were more assignments. $21.05 \%$ of the students claimed that long distance learning is effective due to shorter learning time. The findings of the authors' initial study support the findings [1]

Researchers chose $X$ vocational high school for the preliminary study because $\mathrm{X}$ vocational high school Jakarta is one of the few schools with a focus on accounting and office administration. Research by [2] showed that vocational students majoring in accounting can fulfill the needs of the job market with $69.9 \%$ absorption each year in 5 years of research. Study of vocational high school with office administration majors also shows $90.9 \%$ absorption [3]. Based on the results of research, the two majors have high job absorption which means that they are able to meet 
the needs of job opportunities. In addition, $\mathrm{X}$ vocational high school Jakarta is located in the center of the Indonesian economy which requires human resources to meet the needs of the job market.

Based on several forms of secondary education, vocational high school (SMK) is a formal education that prepares graduates to have advantages in their job [4]. The purpose of SMK is to develop student characteristics in terms of technology, knowledge, and values needed in the field [5]. However, Irwan's study [6] at an SMK through direct observation showed that students struggle with connecting knowledge that has been studied with new knowledge, especially in mathematics. The study also stated that the students did not seem to actively ask questions but more often, they passively listened to directions from the teacher. Students' difficulty in understanding the material is also shown in a research by the Organization for Economic Cooperation and Development's (OECD) [7] with the Program for International Student Assessment (PISA) measuring instrument which measured 15 year old students in various countries in terms of mathematics, science, and literacy skills. The results showed that Indonesia has a value below the average set by PISA [8]

PISA itself is a measuring scale for education that is recognized by many countries, however, Yoon and Järvinen's research [9] shows that South Korea with high PISA scores has low scores in the quality of school life. This shows that these students are not satisfied with school life even though they get high academic scores.

\subsection{Related Work}

Prasstianingrum and Rusmawati's study [10] involving X High School Semarang students showed high scores on quality school life among the students. This means that the students were satisfied with their school life. Similar results were also shown by Tasbihah's research [11] using a similar measuring tool, namely the Quality of School Life Scale (QSL) with Cronbach's Alpha reliability of 0.87 . Reliability in the Tasbihah's research [11] in one of the Indonesian high schools (SMA) is slightly higher than the reliability tested by Leonard [12]. These two studies found that the quality of school life of Indonesian students tends to be high.

Apart from research that measures the quality of school life in students, a number of studies in Indonesia have also been conducted to see the correlation between the quality of school life and other things. Research by Octyavera et al [13] stated that there is a relationship between students' social interactions and the quality of school life. Therefore, by improving the quality of school life, the students' social interaction skills will also increase. Another research [14] stated that the higher the quality of school life, the higher the student's discipline. Other studies have even revealed that high quality of school life will lead to lower truancy among students [15]. From these three studies it can be concluded that the quality of school life is related to other positive things for Indonesian students.

\subsection{Our Contribution}

This research is expected to contribute to the development of psychology, especially educational psychology and scientific studies related to the quality of school life. This research is also expected to make a positive contribution to developing theories in the field of Educational Psychology. The results of this study are expected to provide knowledge for readers of all age and occupation, especially students, teachers, parents, and all parties involved in the learning process at school. This is so that all related parties can improve the quality of school life for students, especially when undergoing distance learning. This research is also expected to be a source of additional information for future researchers who wish to develop research related to the quality of school life with long distance learning.

\subsection{Paper Structure}

This paper consists of introduction, beginning with phenomenon, to reasons for the research. Then, the following literature review contains definitions, dimensions, factors, and some information regarding the quality of school life. The research method section contains the type of research, the sampling technique, the number of participants, and the research setting. The next section is research findings and discussion, and finally, the conclusions of this research.

\section{BACKGROUND}

\subsection{Quality of School Life}

The quality of school life is a combination of positive, negative, and other feelings related to specific domains related to school and its academic results [12]. Ainley and Bourke [16] also stated that the quality of school life is student satisfaction which is influenced by many aspects and is not significantly influenced by student academic achievement. In addition, the quality of school life can also be defined as the feeling of satisfaction felt by students towards the school and their involvement in the school environment [17].

Based on these definitions, it can be concluded that the quality of school life is a feeling of satisfaction and students' views of school, both positive and negative, which is influenced by many aspects. Ainley and Bourke [16] stated that the quality of school life is influenced by several aspects. These aspects are grouped into 2 general dimensions and 5 specific dimensions [12]. Dimensions that affect the quality of school life include: a) General satisfaction, that is student satisfaction with the school in general, describes how students feel when studying every day; b) negative affect describes the negative feelings that students experienced towards school which can cause students to feel angry or anxious; c) students' achievements or views regarding their achievements in school, describing school as a place that makes students feel successful; d) 
social integration is students' views that schools have an important role in developing social skills, describing schools as places for learning to socialize and being recognized by others; e) adventure or students' views of the joy and pleasant feelings they get from school, describing how students enjoy doing assignments; f) teacher or student satisfaction with the relationship or interaction with the teacher, describing the teacher as being fair to students and helping to do their best in learning; g) opportunity or students' views of future opportunities provided by the school, describing schools that help students prepare for the future.

\section{METHODS}

This study is a non-experimental quantitative study. This approach measures the dimensions of the theory-based research variables. This study used descriptive statistical technique to describe the quality of school life at $\mathrm{X}$ vocational high school. The sampling technique used was non-probability sampling. With criterion sampling method, the researchers sought participants who match the characteristics. The final number of participants was 118 students of SMK X Jakarta. Participants were also active students until the 2020-2021 school year. In addition, the research subjects consisted of students in grades 10, 11, and 12 at $\mathrm{X}$ vocational high school Jakarta. The selection of participants is not limited by any particular ethnicity, race, religion, or culture.

\section{FINDINGS AND DISCUSSIONS}

Description of the quality of school life of the study participants uses a scale of 1-4 which has a hypothetical mean of 2.5 while the empirical mean is 2.7796 . Based on the empirical mean score which is greater than the hypothetical mean, it means that the quality of school life at $\mathrm{X}$ vocational high school that implemented long distance learning is high. The general satisfaction dimension has an empirical mean of 2.9619 , higher than the hypothetical mean. Thus, the general satisfaction is high. The negative affect dimension has an empirical mean of 1.7559 , lower than the hypothetical mean. Thus, the negative affect is low. The social integration dimension has an empirical mean of 2.9374, higher than the hypothetical. Thus, the social integration is said to be high. The achievement dimension has an empirical mean of 3.1139, higher than the hypothetical mean. Thus, achievement is considered high. The opportunity dimension has an empirical mean of 3.3884, higher than the hypothetical mean. Thus, opportunity is considered high. The adventure dimension has an empirical mean of 2.0379 , lower than the hypothetical mean. Thus, adventure dimension is considered low. The teacher dimension has an empirical mean of 2.9356, higher than the hypothetical mean. Thus, the teacher dimension is considered high.

Table 1 Overview of each dimension of the quality of school life

\begin{tabular}{|c|c|c|c|c|c|c|}
\hline \multirow{3}{*}{ Dimension of QSL } & \multirow{2}{*}{ Dimension } & \multicolumn{2}{|c|}{ Mean } & \multicolumn{2}{c|}{ Minimum and Maximum } & $\begin{array}{c}\text { Standard } \\
\text { deviation }\end{array}$ \\
\cline { 3 - 7 } & & Empirical & Hipotetic & Min & Max & SD \\
\hline \multirow{4}{*}{ General satifaction } & 2.9619 & 2.500 & 1.83 & 4.00 & 0.46553 \\
\cline { 2 - 7 } & Negative Affect & 1.7559 & 2.500 & 1.00 & 3.60 & 0.61443 \\
\cline { 2 - 7 } & Social Integration & 2.9734 & 2.500 & 1.57 & 4.00 & 0.62462 \\
\cline { 2 - 7 } & Achievement & 3.1339 & 2.500 & 1.60 & 4.00 & 0.53600 \\
\cline { 2 - 7 } & Opportunity & 3.3884 & 2.500 & 1.67 & 4.00 & 0.51331 \\
\cline { 2 - 7 } & Adventure & 2.3079 & 2.500 & 1.00 & 4.00 & 0.50185 \\
\cline { 2 - 7 } & Teacher & 2.9356 & 2.500 & 1.20 & 4.00 & 0.68930 \\
\hline
\end{tabular}

Students' comfort was also measured from the scale of 110. The scale of 1 represents feeling extremely uncomfortable, while the scale of 10 represents feeling extremely comfortable. The results of data processing showed that the empirical mean score for this question was 5.9492. The hypothetical mean score is smaller than the empirical mean score of 5.5, thus the comfort of the $\mathrm{X}$ vocational school students is considered high. In addition, the reason students feel comfortable with long distance learning is due to the effectiveness of learning time and break time which is expressed by 46 students. Students claimed that they can lie down or generally relax while learning takes place. Students also explained that they can wake up later compared to when learning was done traditionally.
In addition, 14 participants claimed that they can replay the recorded lessons, if they did not understand the lesson the first time. 15 students also feel comfortable because they don't have to meet many people and can do things they like when learning, such as listening to music. In addition, students also felt that being at home makes them closer to family. 38 other participants gave various answers, including enjoying the friendly attitude of the teachers, participating in preventing the spread of the Covid-19 virus, not feeling comfortable, and more.

Meanwhile, the reason the students felt uncomfortable with long distance learning was that the assignments increased in difficulty and quantity, as claimed by 47 students. In addition, the second most common reason as explained by 30 participants was that the delivery of material was 
difficult to understand. These findings are similar to a comparative study by Hong et al [1] of students in China. Other reasons students feel uncomfortable are unstable internet connection, difficulty in self-regulation while at home, boredom, and others.

\section{CONCLUSIONS}

This study shows that the quality of school life in vocational high schools that implement long distance learning tends to be high. Students also claim to be comfortable with long distance learning. However, there is a need to increase student comfort with reduced assignments, more innovative methods of delivering material, and assistance for solving internet connection issues.

\section{ACKNOWLEDGMENT}

This research is part of the Faculty of Psychology at Universitas Tarumanagara.

\section{REFERENCES}

[1] Hong, Y., Li, X., Lin, Y., Xie, J., Yan, X., \& Lin, Z. (2020). A Comparative Study of Online Education and Traditional Offline Education During COVID-19.

[2] Ningsih, D. R. (2016). POTRET LULUSAN SEKOLAH MENENGAH KEJURUAN SMK) PROGRAM KEAHLIAN AKUNTANSI DENGAN DUNIA KERJA DI SMK NEGERI 1 NGAWI. Spektrum Analisis Kebijakan Pendidikan, 5(5), 537-547.

[3] Santoso, A. B., Ninghardjanti, P., \& Rapih, S. (2018), Analisis Relevansi Lulusan Kompetensi Keahlian Administrasi Perkantoran Dengan Dunia Kerja. In Prosiding Seminar Nasional Pendidikan Administrasi Perkantoran.

[4] Khurniawan, A. W., \& Haryani, T. (2016). Grand Design Pengembangan Teaching Factory dan Technopark di SMK. Jakarta: Direktorat Pembinaan Sekolah Menengah Kejuruan. Direktorat Jenderal Pendidikan Dasar dan Menengah Kementerian Pendidikan dan Kebudayaan.

[5] Murniati, A. R., \& Usman, N. (2009). Implementasi manajemen stratejik dalam pemberdayaan sekolah menengah kejuruan. Perdana Publishing.

[6] Irwan, Y. (2018). Rekonstruksi Materi Pendidikan Agama Islam Dalam Upaya Meningkatkan Jiwa Kewirausahaan Siswa Sekolah Menengah
Kejuruan (Doctoral dissertation, Universitas Islam Negeri Sultan Syarif Kasim Riau).

[7] CEOWORLD, M. (2020, 16 September). The world's best countries for the education system. ceoworld.biz https://ceoworld.biz/2020/05/10/rankedworlds-best-countries-for-education-system-2020/

[8] OECD. (2019). PISA 2018 Results: combined Executive Summaries.

[9] Yoon, J., \& Järvinen, T. (2016). Are model PISA pupils happy at school? Quality of school life of adolescents in Finland and Korea. Comparative Education, 52(4), 427-448.

[10] Prasstianingrum, N. E., \& Rusmawati, D. (2014). Hubungan antara quality of school life dengan motivasi belajar pada siswa kelas XI SMA Islam Sultan Agung 1 Semarang. Empati, 3(2), 267-279.

[11] Tasbihah, M. L. (2019). Pengaruh Quality of School Life terhadap perilaku disiplin pada siswa SMA A. Wahid Hasyim (Doctoral dissertation, UIN Sunan Ampel Surabaya).

[12] Leonard, C. A. R. (2002). Quality of school life and attendance in primary schools. Unpublished doctoral dissertation, University of Newcastle, Australia.

[13] Octyavera, R. M., Siswati, S., \& Sawitri, D. R. (2009). Hubungan kualitas kehidupan sekolah dengan penyesuaian sosial pada siswa sma international islamic boarding school republic of Indonesia. Jurnal Psychoidea.

[14] Febriani, N., Widodo, P. B., \& Kristiana, I. F. (2013). Hubungan antara Kualitas Kehidupan Sekolah dengan Kedisiplinan Siswa Kelas Berpindah pada Kelas XII SMAN 3 Semarang. Jurnal Psikologi, 12(2), 152163

[15] Almaliki, S. (2018). Hubungan antara quality of school life dengan perilaku membolos pada siswa Madrasah Tsanawiyah (Doctoral dissertation, UIN Sunan Ampel Surabaya).

[16] Ainley, J., \& Bourke, S. (1992). Student views of primary schooling. Research Papers in Education, 7(2), $107-128$

[17] Karatzias, A., Power, K. G., \& Swanson, V. (2001). Quality of school life: Development and preliminary standardisation of an instrument based on performance indicators in Scottish secondary schools. School Effectiveness and School Improvement, 12(3), 265-284 